\title{
Tropical Pacific Decadal Variability and the Subtropical-Tropical Cells
}

\author{
KATJA LOHMANN \\ Max-Planck-Institut für Meteorologie, Hamburg, Germany \\ MoJiB LATIF \\ Leibniz-Institut für Meereswissenschaften, Kiel, Germany
}

(Manuscript received 21 May 2004, in final form 27 May 2005)

\begin{abstract}
The decadal-scale variability in the tropical Pacific has been analyzed herein by means of observations and numerical model simulations. The two leading modes of the sea surface temperature (SST) variability in the central western Pacific are a decadal mode with a period of about $10 \mathrm{yr}$ and the ENSO mode with a dominant period of about $4 \mathrm{yr}$. The SST anomaly pattern of the decadal mode is ENSO like. The decadal mode, however, explains most variance in the western equatorial Pacific and off the equator. A simulation with an ocean general circulation model (OGCM) forced by reanalysis data is used to explore the origin of the decadal mode. It is found that the variability of the shallow subtropical-tropical overturning cells is an important factor in driving the decadal mode. This is supported by results from a multicentury integration with a coupled ocean-atmosphere general circulation model (CGCM) that realistically simulates tropical Pacific decadal variability. Finally, the sensitivity of the shallow subtropical-tropical overturning cells to greenhouse warming is discussed by analyzing the results of a scenario integration with the same CGCM.
\end{abstract}

\section{Introduction}

The sea surface temperature (SST) in the tropical Pacific exhibits pronounced decadal-scale variability. Trenberth and Hurrell (1994) and Graham (1994) describe this decadal variability in detail and conclude that it originates in the tropical Pacific itself. Gu and Philander (1997, hereafter GP97), on the other hand, propose that the decadal variability in the tropical $\mathrm{Pa}$ cific is part of a cycle that involves the Tropics and the extratropics, in which the mean advection of temperature anomalies from the extratropics to the Tropics plays a crucial role and determines the decadal time scale. Barnett et al. (1999) offer an alternative explanation. They argue that decadal variability in the North Pacific reaches into the Tropics and drives part of the tropical decadal variability through atmospheric teleconnections.

Several other studies suggest an influence of the shallow subtropical overturning cells (STCs) onto the SST

\footnotetext{
Corresponding author address: Katja Lohmann, Nansen Environmental and Remote Sensing Center, Thormøhlensgate 47, 5006 Bergen, Norway.

E-mail: katja.lohmann@nersc.no
}

variability in the tropical Pacific. The STCs are mainly wind-driven meridional overturning cells that were first described by McCreary and Lu (1994) and Liu (1994). In the zonal integral they appear as closed cells with an upwelling at the equator, a poleward Ekman transport at the surface, subduction in the subtropics, and an equatorward return flow within the thermocline. It is unclear, however, if these cells are really closed. Johnson (2001), for instance, suggests from drifter data analysis that the poleward surface limb does not reach the subduction areas in the east. The equatorial upwelling is partly balanced by downwelling within the Tropics (at about $5^{\circ} \mathrm{S}$ and $5^{\circ} \mathrm{N}$ ) forming relatively narrow recirculation cells, which are referred to as tropical cells (TCs; Lu et al. 1998). The appearance of the TCs, however, can depend on the way the meridional overturning streamfunction is calculated (Hazeleger et al. 2003). The potential influence of the STCs onto the SST is due to 1) the spinup and -down of the cells leading to anomalies in the equatorward transport and upwelling strength of cold subsurface water and 2) the advection of temperature anomalies by the mean flow from the subtropical subduction areas. These two mechanisms are referred to as the 1) $v^{\prime} \bar{T}$ and 2) $\bar{v} T^{\prime}$ mechanisms, respectively. 
The first mechanism was suggested by Kleeman et al. (1999) from analysis of the tropical decadal variability simulated by a $31 / 2$-layer ocean model coupled to a statistical atmosphere. Further supporting model studies were performed by Klinger et al. (2002) and Solomon et al. (2003) using the same ocean model and by Nonaka et al. (2002) who used an ocean general circulation model (OGCM) forced by observed wind stresses. Merryfield and Boer (2005) analyzed a coupled general circulation model (CGCM) simulation and found the $v^{\prime} \bar{T}$ mechanism to be the dominating one. McPhaden and Zhang (2002) reported by investigating hydrographic data and observed SST that the warming of the tropical Pacific in the last decades was associated with a decrease in the strength of the STCs.

The second mechanism was described by GP97 using a simple box model, by Zhang et al. (1998) analyzing the Levitus data, and by Giese et al. (2002) using an OCGM. Schneider et al. (1999), however, suggested from OGCM experiments that the subducted temperature anomalies from the subtropics do not affect the equatorial SST. This was supported by Hazeleger et al. (2001) who did not find any propagation of temperature anomalies to the equator in a combined model and observational study. Yang and Liu (2004, submitted to J. Climate) found both mechanisms of importance in their CGCM experiments. In a recent study, Boccaletti et al. (2004, submitted to J. Climate) proposed that a heat loss in higher latitudes leads via wave propagation to changes in the depth of the thermocline and thus to a heat gain at low latitudes.

In this study, we use observed SSTs in combination with an ocean general circulation model forced by $\mathrm{Na}$ tional Centers for Environmental Prediction-National Center for Atmospheric Research (NCEP-NCAR) reanalysis data as well as a coupled atmosphere-ocean general circulation model to investigate the decadal variability in the tropical Pacific. Special attention is given to the role of the subtropical-tropical cells. The paper is organized as follows: section 2 gives a short overview of the data. The observed decadal variability in the tropical Pacific SST and its relationship to the TCs and STCs (from the ocean model forced with the NCEP-NCAR reanalysis) are described in sections 3 and 4 , respectively. Section 5 discusses the results from the coupled model experiments, and the main conclusions are given in section 6 .

\section{Data}

The observed SST is taken from the Hadley Center Ice and Sea Surface Temperature (HadISST1) dataset encompassing the years 1870-1998 (Rayner et al. 2003).
To get further insight into the dynamics of the observed SST variability, we analyze a 54-yr integration of the Max-Planck-Institut für Meteorologie ocean general circulation model (MPI-OM) forced by the NCEPNCAR reanalysis (Kalnay et al. 1996) for the years 1948-2001. The MPI-OM model, described by Marsland et al. (2003), is a new version of the Hamburg Ocean Primitive Equation (HOPE) model using a C grid and orthogonal curvilinear coordinates. The OGCM was used by Latif et al. (2004) in coupled mode using the atmosphere model ECHAM5 to study the multidecadal variability in the North Atlantic. The horizontal resolution amounts to about $3^{\circ} \times 3^{\circ}$. The grid has a meridional refinement at the equator, with $0.5^{\circ}$ resolution between $10^{\circ} \mathrm{S}$ and $10^{\circ} \mathrm{N}$. Vertically, 23 levels were used, of which 10 are in the upper $300 \mathrm{~m}$. The surface heat flux was not taken from the NCEPNCAR reanalysis, but calculated according to bulk formulas (see Marsland et al. 2003). Initial conditions were obtained from an extended-range integration with climatological forcing.

To separate the effects of the equatorial and offequatorial winds upon the variability of the TCs and STCs, two wind sensitivity experiments with the MPIOM model were performed. In the "no equator" experiment the wind stress forcing from the NCEPNCAR reanalysis is set to the climatological annual cycle between $5^{\circ} \mathrm{S}$ and $5^{\circ} \mathrm{N}$. In the "only equator" experiment climatological wind stress forcing is prescribed poleward of $5^{\circ}$ latitude. Both experiments contain transition zones between $5^{\circ}$ and $8^{\circ}$ latitude in which the anomalies (from the climatological annual cycle) change linearly.

Additionally, we analyze a 300-yr control integration of the coupled general circulation model ECHAM4/ OPYC3. The atmosphere model is ECHAM4 (Roeckner et al. 1996) with 19 vertical levels and a horizontal resolution of T42 corresponding to about $2.8^{\circ} \times 2.8^{\circ}$. The Oberhuber Ocean Isopycnal model (OPYC; Oberhuber 1993) is based on the primitive equations and has an embedded mixed layer model. The OGCM has a horizontal resolution of $2.8^{\circ} \times 2.8^{\circ}$ with a gradual meridional refinement in the subtropical-tropical region and a meridional resolution of $0.5^{\circ}$ in the equatorial region. It was run with 11 vertical density layers, and the output was interpolated onto fixed depth levels: 48 for the meridional overturning (18 in the upper $300 \mathrm{~m}$ ) and 10 for the other variables (5 in the upper $300 \mathrm{~m}$ ). Additionally, we analyze the results of a 240-yr-long greenhouse warming simulation (Roeckner et al. 1999). The increase in $\mathrm{CO}_{2}$ is prescribed from observations from 1860 up to the present and follows the Intergovernmental Panel on Climate Change (IPCC) 1992a sce- 


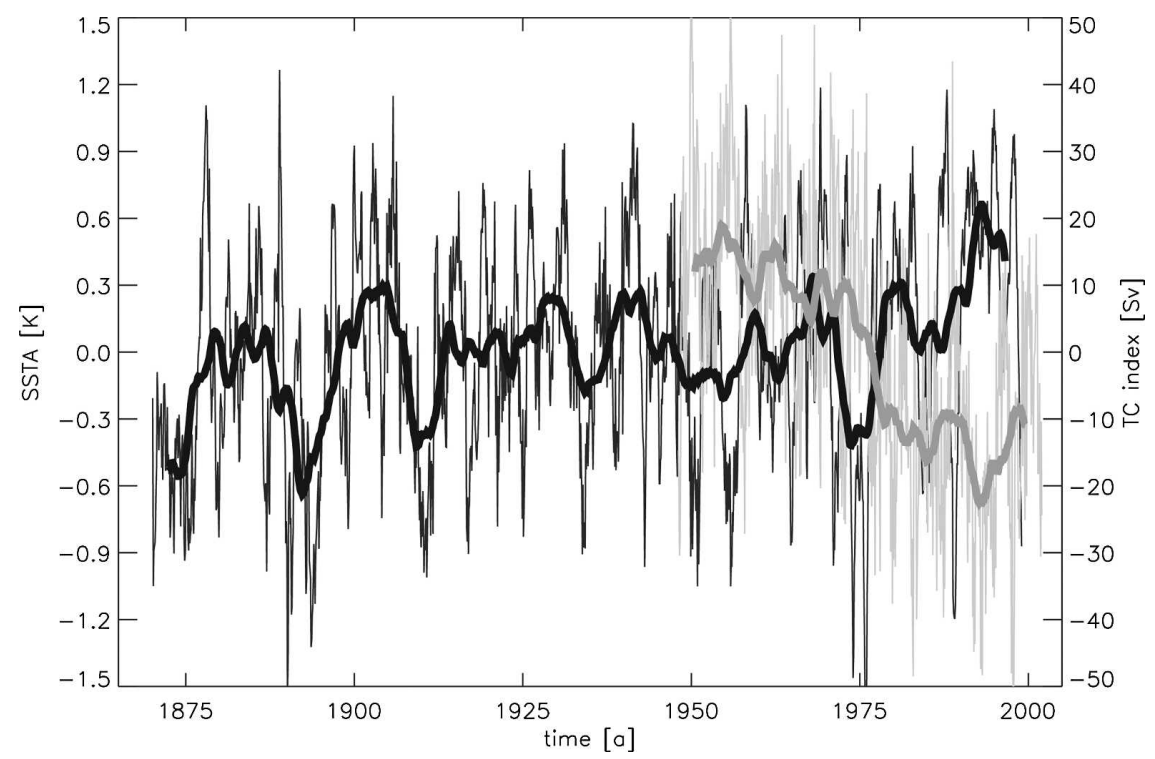

FIG. 1. Time series of the observed Niño-4 SST anomalies and the anomalous strength of the TCs taken from an ocean model forced with the NCEP-NCAR reanalysis. For definition of the cell strength see text. Shown are monthly values with the annual cycle removed (thin lines: black for SST, gray for TC) and 5-yr running mean (thick lines: black for SST, gray for TC).

nario (Houghton et al. 1995) until 2100. All data used in this study are monthly values with the mean annual cycle removed.

\section{Observed variability in Niño-4 SST}

Observations indicate that the decadal SST variability is particularly strong in the western-central equatorial Pacific (e.g., Trenberth and Hurrell 1994; Graham 1994). We have chosen, therefore, the Niño-4 region $\left(5^{\circ} \mathrm{N}-5^{\circ} \mathrm{S}, 160^{\circ} \mathrm{E}-150^{\circ} \mathrm{W}\right)$ to begin our analysis of the decadal variability. Figure 1 shows the observed sea surface temperature anomalies (SSTA) averaged over the Niño-4 region from 1870 onward. The time series exhibits decadal fluctuations of the order of $\pm 0.6^{\circ} \mathrm{C}$ with interannual variability superimposed. To highlight the decadal variability, a 5-yr running mean is also shown. It is interesting that the relatively strong dip in SST in the 1970s is not unusual in the context of the last $130 \mathrm{yr}$. We note also that there is a rather strong trend in the Niño-4 SSTA time series during the last few decades.

We decomposed the monthly Niño-4 SSTA time series by means of a singular spectrum analysis (SSA). The reconstructed Niño-4 SSTA time series using the first two SSA modes (pairs) are shown in Fig. 2. The leading temporal mode, accounting for about $25 \%$ of the variance of the Niño-4 index, has a quasi-decadal time scale (Fig. 2a). It closely resembles the low-passfiltered curve (5-yr running mean) shown in Fig. 1. The second-most energetic mode (Fig. 2b) corresponds to the well-known interannual variability associated with the El Niño-Southern Oscillation (ENSO) phenomenon. It explains about $20 \%$ of the variance. We note that the warming trend in the western equatorial Pacific seen in Fig. 1 projects only onto the decadal, but not onto the ENSO, mode. The ENSO mode also exhibits pronounced decadal-scale variability, which is seen as an amplitude modulation. The processes behind this amplitude modulation are still highly controversial. No clear trend in the ENSO amplitude is seen in the corresponding SSA reconstruction, so that the interpretation of the climate change in the tropical Pacific observed during the recent decades is as follows: The more frequent and stronger El Niño events during the 1990s are probably due to the positive swing in the decadal mode, which simply shifts the "working point" for ENSO toward the positive side (see also Latif et al. 1997). This means that the El Niños of 1982-83 and 1997-98 may have become record events, because there is an upward trend in the decadal mode, and since the decadal mode was additionally in a positive extreme phase. Thus, one may argue that the background conditions upon which ENSO operates have changed, but ENSO itself did not.

Next, we computed by means of linear regression the spatial structures associated with the two leading temporal modes, as expressed by the corresponding reconstructions (Fig. 2). The two regression patterns and the 


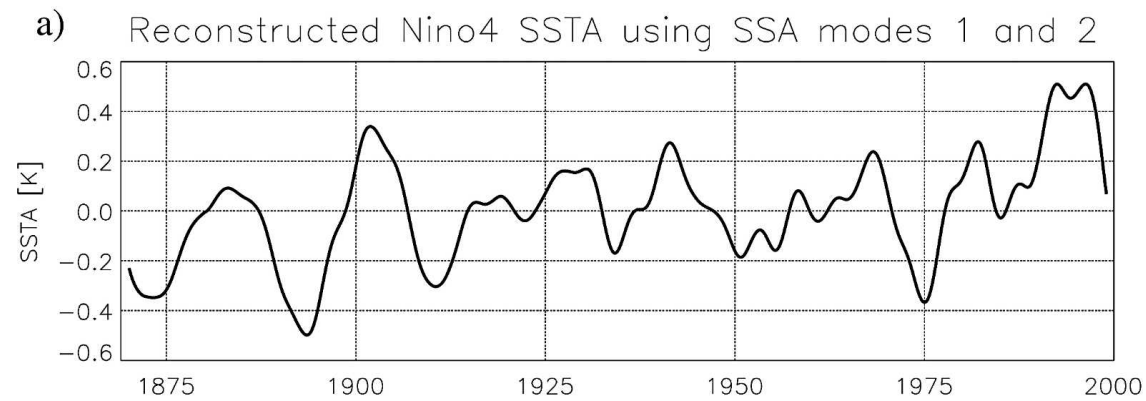

b) Reconstructed Nino4 SSTA using SSA modes 3 and 4

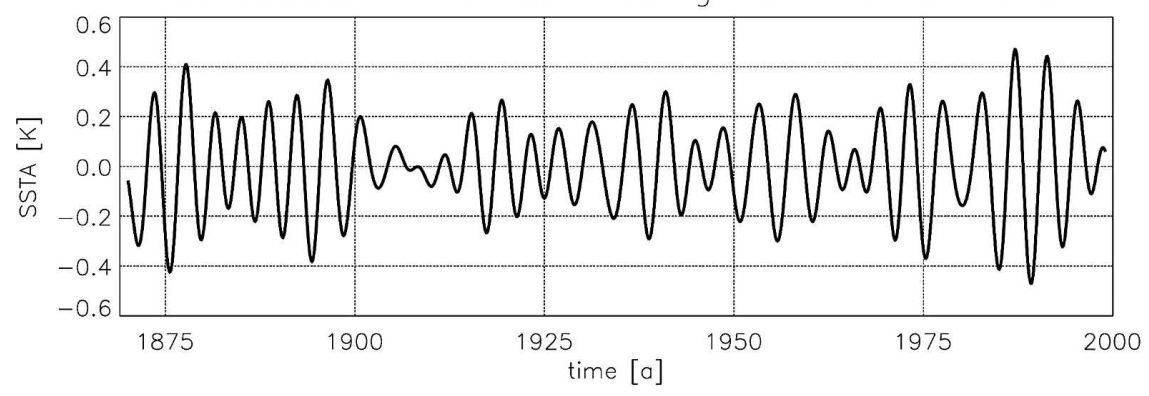

FIG. 2. Reconstruction of the monthly observed Niño-4 SST anomalies from the SSA using (a) modes 1 and 2 and (b) modes 3 and 4 .

associated explained variances are shown in Figs. 3 and 4 , respectively. The decadal mode is El Niño like (Fig. 3a), as described in other papers (e.g., Zhang et al. 1997). However, there are important differences to the canonical El Niño structure. The regression pattern for the decadal mode is broader in the meridional direction and stronger in the western than in the eastern equatorial Pacific. Near the date line, the regression coefficients amount to about $0.3^{\circ} \mathrm{C}$ per standard deviation of the decadal mode time series (Fig. 2a).

The interannual mode shows the typical El Niño structure, with strongest anomalies in the eastern and central equatorial Pacific (Fig. 3b). Maximum regression coefficients reach $0.4^{\circ} \mathrm{C}$ per standard deviation of the ENSO mode time series (Fig. 2b). The associated explained variances also differ between the two modes. The decadal mode (Fig. 4a) shows a horseshoe-like structure in the explained variances, with maximum values in the western equatorial Pacific and off the equator, but low explained variances in the eastern equatorial Pacific. The interannual mode (Fig. 4b), on the other hand, explains the most variance at the equator. Please note that the largest explained variances must occur in the Niño-4 region, since the corresponding SSTA time series was used in the SSA.

\section{Relation of the decadal mode to the (S)TCs}

We discuss now the relationship between the observed decadal SST variations in the Niño-4 region and the variability of the tropical (TCs) and subtropical (STCs) cells derived from the NCEP-NCAR reanalysis forced ocean model integration. Indices for the strength of the TCs and the STCs were defined by taking for each time step $\mathrm{psi}_{\max }\left(5^{\circ} \mathrm{S}-5^{\circ} \mathrm{N}\right.$, upper $\left.250 \mathrm{~m}\right)-$ $\mathrm{psi}_{\text {min }}\left(5^{\circ} \mathrm{S}-5^{\circ} \mathrm{N}\right.$, upper $\left.250 \mathrm{~m}\right)$, and $\mathrm{psi}_{\max }\left(10^{\circ} \mathrm{N}\right.$, upper $250 \mathrm{~m})-\mathrm{psi}_{\min }\left(10^{\circ} \mathrm{S}\right.$, upper $\left.250 \mathrm{~m}\right)$, respectively, where psi is the Pacific meridional overturning streamfunction (the overturning is negative for the southern cell). The STC index is defined at $10^{\circ}$ latitude to be outside the range of the TCs. Further dependance on latitude is discussed below (Figs. 5 and 6). To account for the fact that the surface branches of the cells are spinning up and down quicker than the pycnocline branches (Liu 1998; Klinger et al. 2002; Merryfield and Boer 2005), the decadal variability of the TCs and STCs discussed in this study is determined from overturning data with a 5-yr running mean applied. In Fig. 1, both the raw and the low-pass-filtered TC indices are shown in addition to the Niño-4 SSTA time series.

We now concentrate on the decadal time scale and consider quantities that were smoothed by a 5-yr running mean filter. The TC and Niño-4 SSTA time series (Fig. 1) as well as the STC and Niño-4 SSTA time series (not shown) are strongly anticorrelated, so that anomalously warm Niño-4 SST goes along with anomalously weak overturning cells. For the TCs, the correlation coefficient between the two (low-pass filtered) time series amounts to -0.7 , with the overturning leading by a 
a)

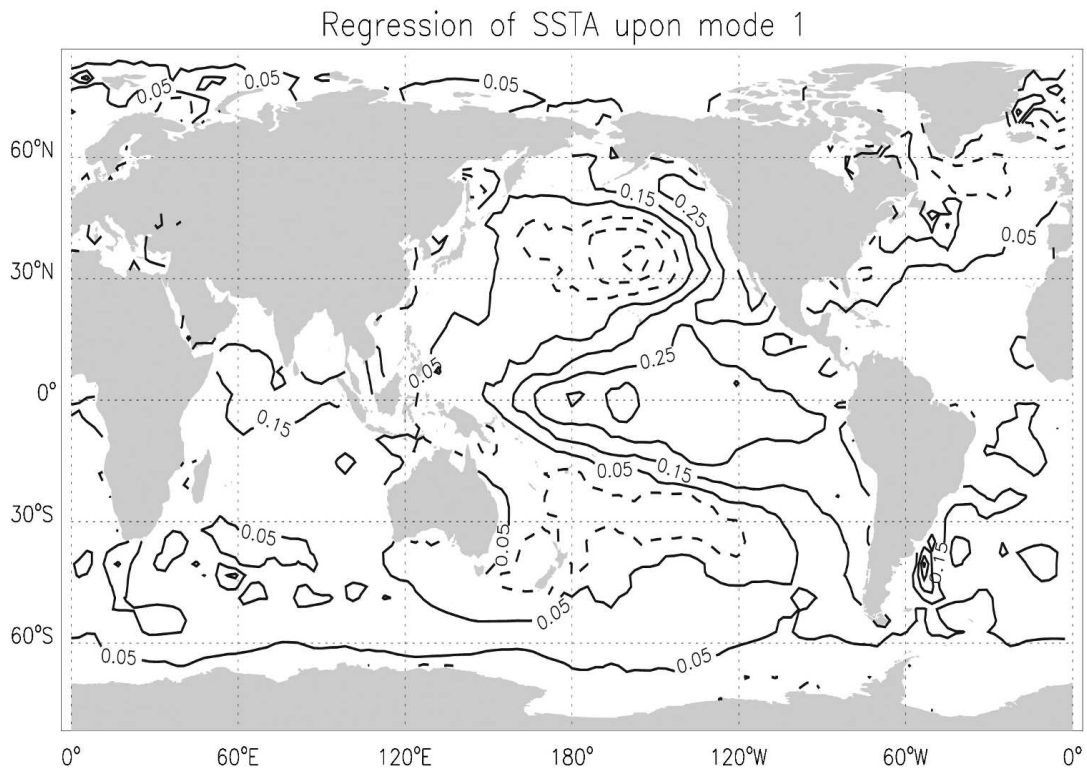

b)

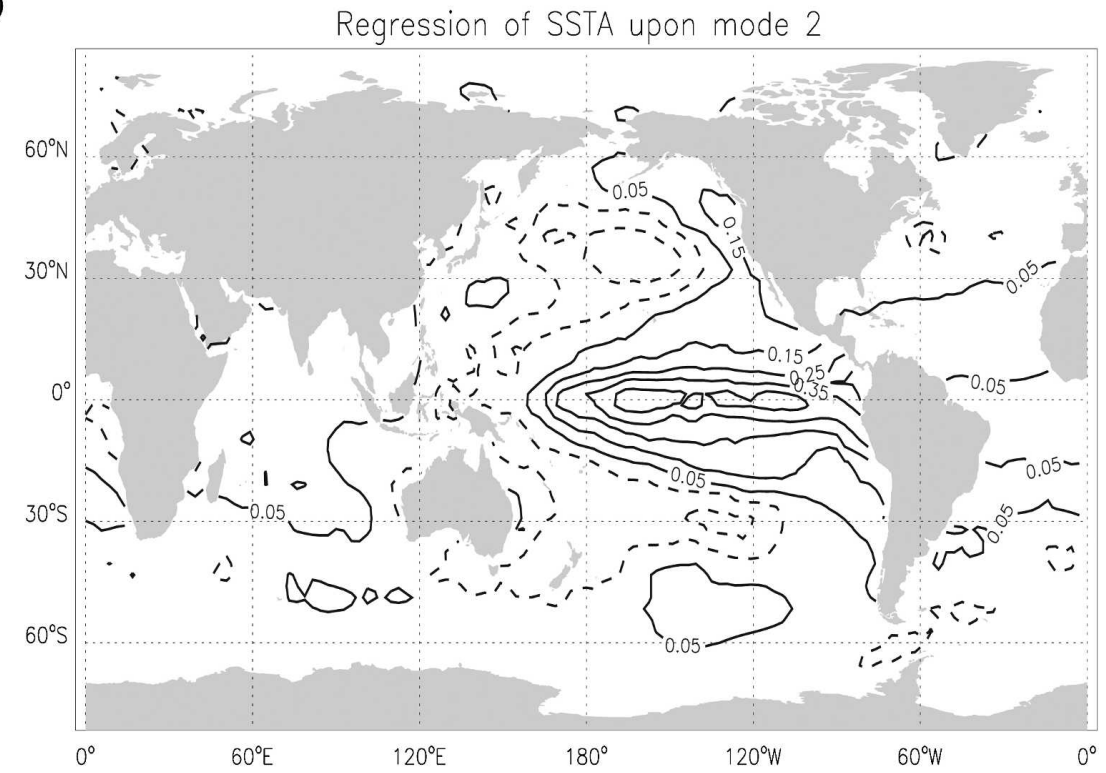

FIG. 3. Regression of the monthly global observed SST onto the Niño-4 modes shown in Fig. 2: (a) decadal and (b) interannual mode. Units are K per standard deviation Niño-4 SST. The standard deviation is $0.21 \mathrm{~K}$ for the decadal and $0.18 \mathrm{~K}$ for the interannual mode. Contour levels are $\pm 0.05,0.15,0.25,0.35$, and $0.45 \mathrm{~K}$.

few months (solid line in Fig. 5). The time lag indicates that the variability of the TCs is indeed driving the decadal SST fluctuations in the Niño-4 region. Considering the northern and the southern TCs separately, the lag is about 2 month for the southern and 7 month for the northern cell.

Considering the STCs, the largest correlation coefficient between the low-pass-filtered cell strength index and Niño-4 SSTAs amounts to -0.6 (long dashed line in Fig. 5), which is lower compared to the TCs but statistically significant at the $95 \%$ level (threshold value -0.44 according to a $t$ test). The changes in the STC strength lead the changes in SST by about 15 months. Compared to the TCs the lag is increasing, indicating that the STCs spin up and down slower than the narrow TCs. The lag is consistent with Nonaka et al. (2002) who found a lag of about 2 yr between the equatorial temperature anomalies simulated by an ocean model 
a) Variance explained in SSTA by mode 1

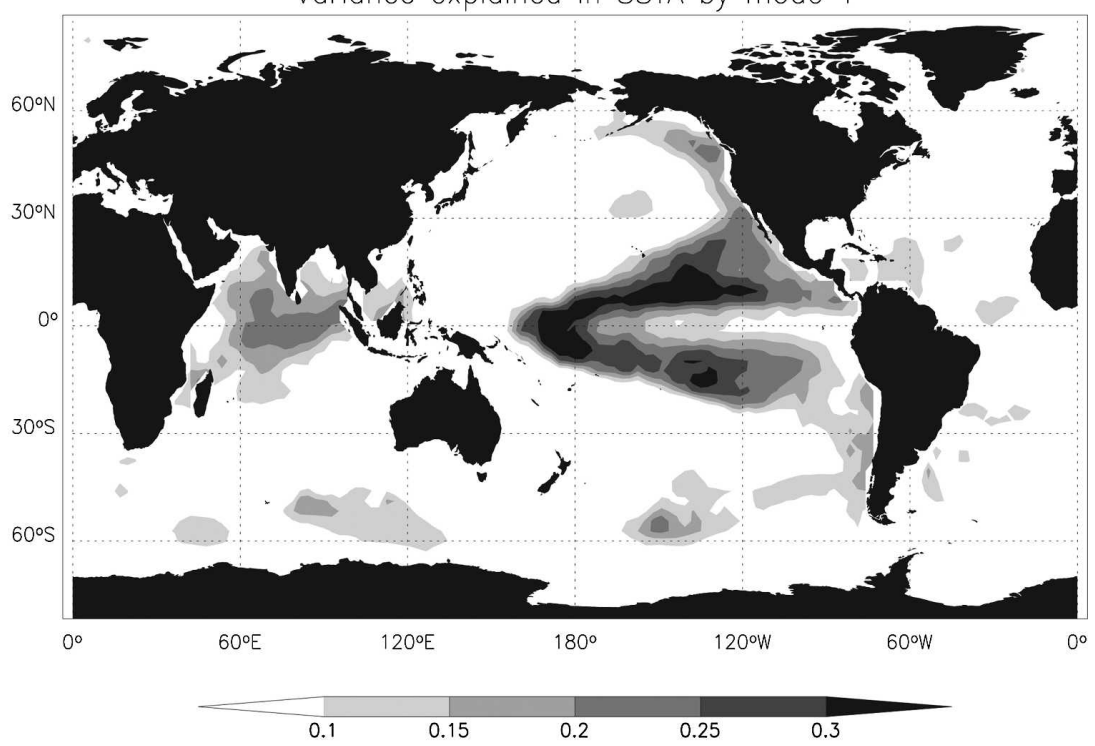

b) Variance explained in SSTA by mode 2

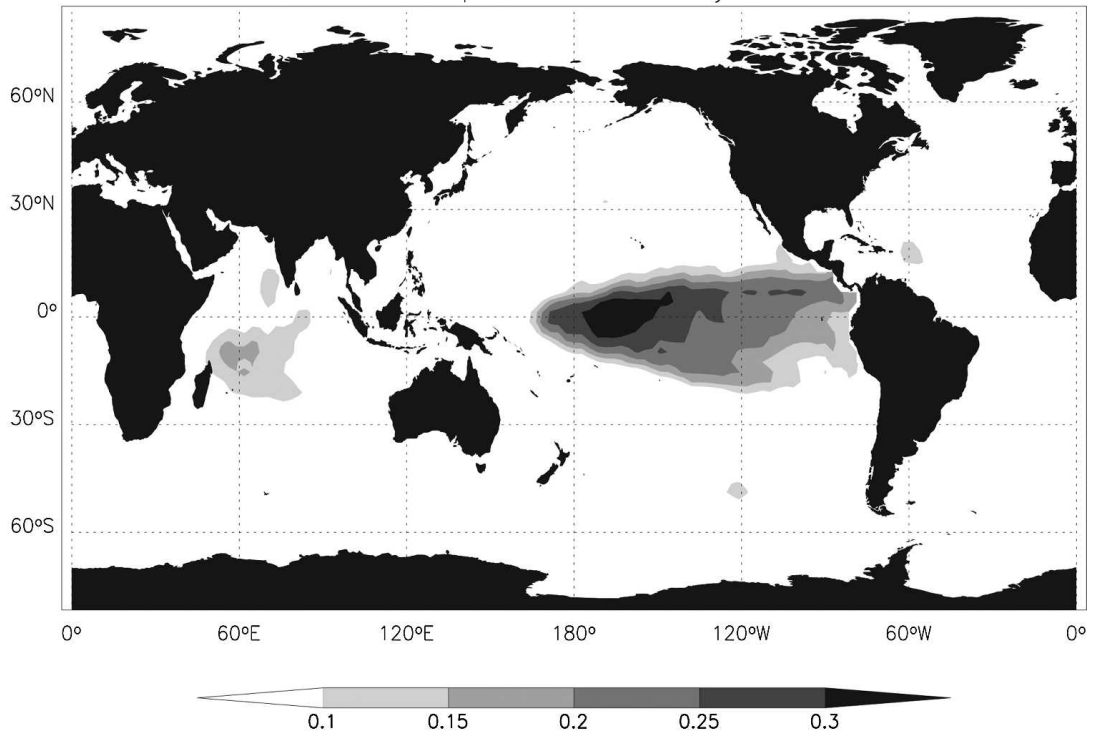

FIG. 4. Explained variance of the regression pattern shown in Fig. 3: (a) for the regression upon the decadal mode and (b) for the regression upon the interannual mode.

forced with no equatorial winds and those from an ocean model forced by only equatorial winds. Therefore we suggest that the STCs have an influence on the (western) equatorial SST. We also determined the cross-correlation function between the low-passfiltered Niño-4 SSTAs and indices of the decadal STC strength computed from different latitudes (shortdashed and dashed-dotted lines in Fig. 5). With increasing distance from the equator the correlation coefficient decreases and the lag between STC and SST anomalies increases. However, poleward of $15^{\circ}$ lati- tude, the correlation drops to a value close to the significance level. The fact that the trend in the STC strength vanishes at about $15^{\circ}$ latitude might contribute to the low correlations. Also Fig. 6 does not show a signal in the overturning poleward of $15^{\circ}$ latitude during phases of anomalously warm (cold) Niño-4 SST.

The spatial correlation pattern between the decadal TC strength index (Fig. 1) and the observed SSTs as well as between the decadal STC strength index and the observed SSTs closely resembles that shown in Fig. 4a in the tropical Pacific (the equatorial horseshoe-like 


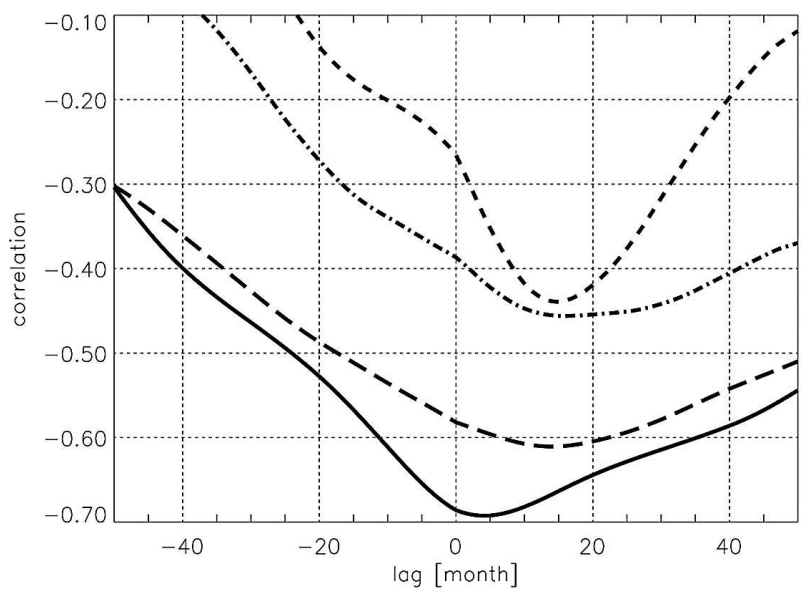

FIG. 5. Cross-correlation function between the decadal observed Niño-4 SST (Fig. 1, years 1948-98) and the strength of the TCs and STCs (at different latitudes) taken from an ocean model forced with the NCEP-NCAR reanalysis: TC (solid line), STC at $10^{\circ}$ latitude (long-dashed line), STC at $17.5^{\circ}$ latitude (shortdashed line), and STC at $25^{\circ}$ latitude (dashed-dotted line). For definition of the cell strength see text. The $95 \%$ significance level according to a $t$ test is -0.44 . A positive (negative) lag indicates that the Niño-4 SST is lagging (leading).

structure), indicating that the influence of the cells is higher in the western than in the eastern equatorial Pacific.

The most striking feature in our OGCM simulation is the spindown of the TCs (Fig. 1) and STCs (not shown)

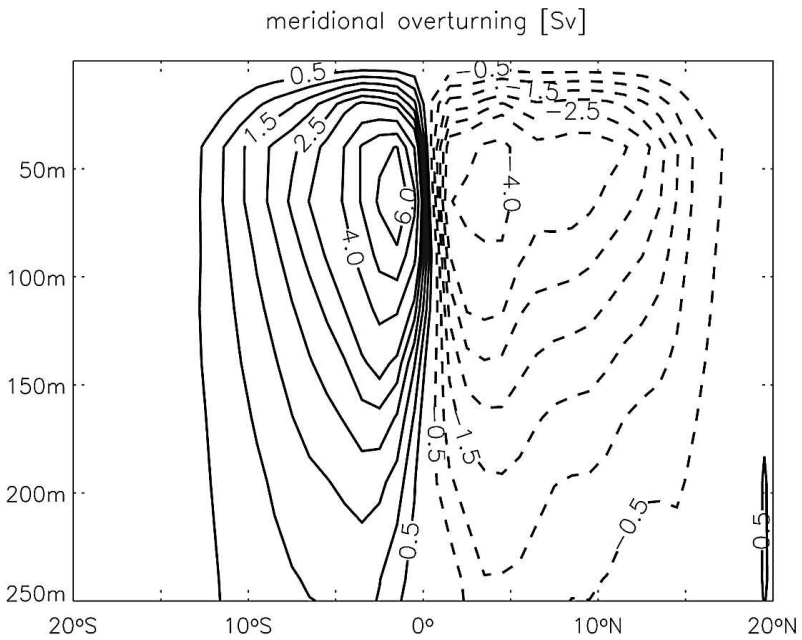

FIG. 6. Regression of the monthly Pacific meridional overturning streamfunction (with the annual cycle removed) onto the observed decadal Niño-4 SST mode from Fig. 2a. The overturning is taken from an ocean model forced with the NCEP-NCAR reanalysis. Units are $\mathrm{Sv}\left(1 \mathrm{~Sv} \equiv 10^{6} \mathrm{~m}^{3} \mathrm{~s}^{-1}\right)$ per standard deviation SST $(0.21 \mathrm{~K})$. Contour levels are $\pm 0.5,1,1.5,2,2.5,3,4,5$, and 6 Sv. Note that for the Southern Hemisphere the mean overturning is negative; i.e., negative (positive) values correspond to a strengthening (weakening). over the last $50 \mathrm{yr}$, which goes along with a warming of the Niño-4 SST. Wu and Xie (2003) call for caution in studies of the tropical Pacific variability based on NCEP-NCAR-forced ocean models due to differences in NCEP-NCAR- and Comprehensive OceanAtmosphere Data Set (COADS) winds. This trend, however, has been also found by McPhaden and Zhang (2002) who used hydrographic data. They determined the pycnocline transports at about $9^{\circ}$ latitude and computed the convergence of the transports to obtain a measure of the STC strength. Furthermore, the trend is simulated in each individual member of an ensemble of integrations with the MPI-OM model, run with a coarser horizontal (but higher vertical) resolution, in which the initial conditions were varied (not shown). This was achieved by conducting 10 integrations with identical forcing. The initial conditions for each ensemble member were taken from the state simulated at the end of the preceeding member. It is therefore unlikely that the strong downward trends seen in our model simulations arise from problems associated with the OGCM initialization.

Figure 6 shows the pattern for the regression of the Pacific meridional overturning streamfunction onto the decadal Niño-4 SST mode (Fig. 2a). It shows a rather broad pattern indicating that not only the TCs but also the STCs have some influence upon the decadal SST variability. This is in contrast to the interannual (ENSO) Niño-4 SST mode (Fig. 2b) for which the overturning regression pattern is limited to about $5^{\circ}$ latitude (not shown). Again, this indicates that the STCs need more time to spin up and down than the TCs. Figure 6 also suggests an influence from both hemispheric cells. We note that for the Southern Hemisphere the mean overturning is negative; that is, positive anomalies correspond to a weakening. The slightly weaker values for the Northern Hemisphere might be partly due to the fact that the overturning is weaker in the mean $(25 \mathrm{~Sv}$ for the northern compared to $40 \mathrm{~Sv}$ for the southern TC, where $1 \mathrm{~Sv}=10^{6} \mathrm{~m}^{3} \mathrm{~s}^{-1}$ ). It follows from the regression pattern that a change of about $0.2^{\circ} \mathrm{C}$ (standard deviation of the decadal Niño-4 SST) goes along with a change of the shallow meridional overturning by about $15 \%-20 \%$.

To further investigate the dynamics of the decadal tropical SST variability we regress various atmospheric and oceanic fields from the NCEP-NCAR-forced ocean model integration onto the decadal mode time series (Fig. 2a). The regression patterns are shown in Fig. 7. A warming (cooling) in the Niño-4 region goes along with a weakening (strengthening) of the trade winds over nearly the whole tropical Pacific domain (vectors in Fig. 7a). The changes are of the order of 

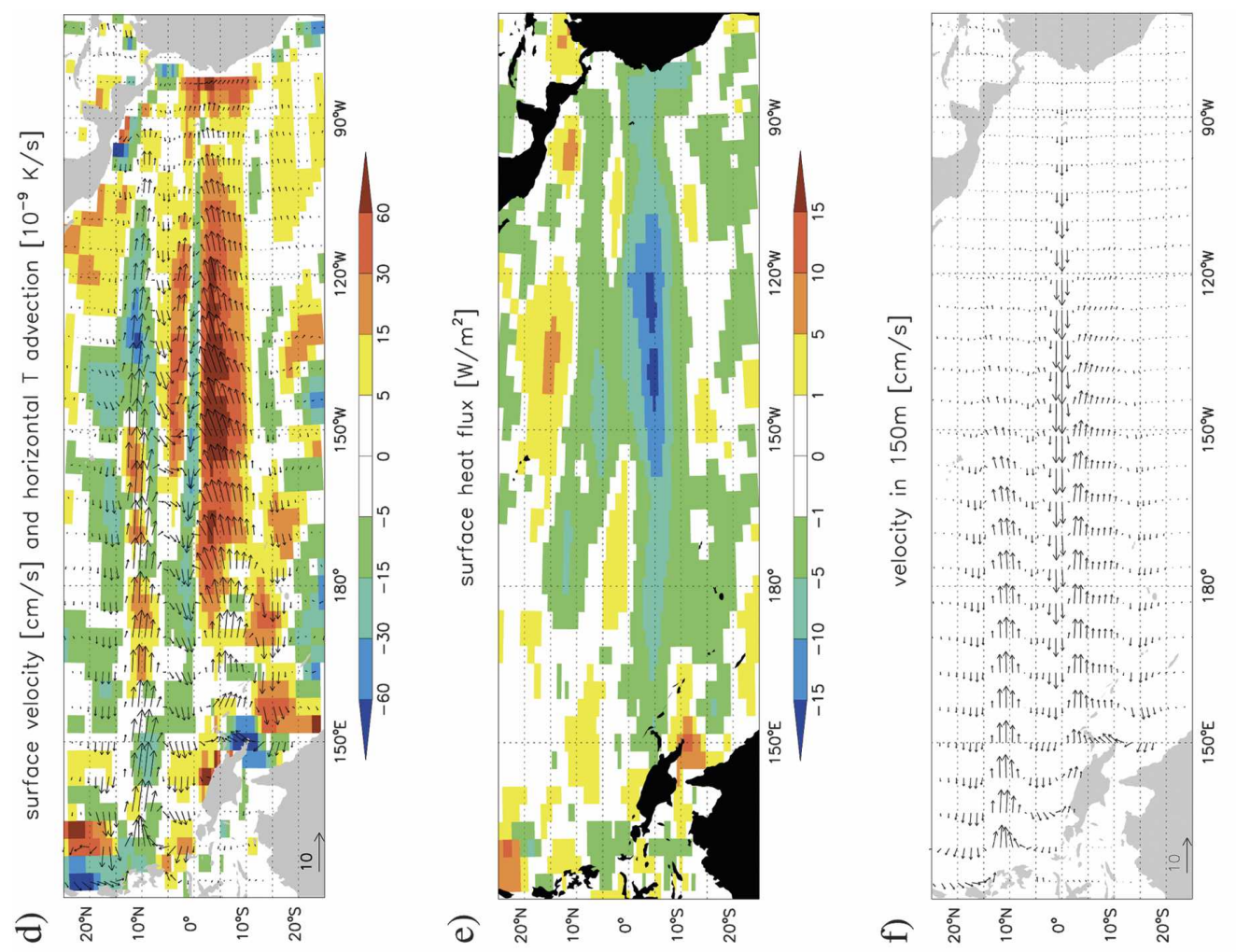

ङ ฮิ่

荨 $\ddot{\bar{\Delta}} \Xi$

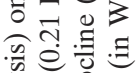

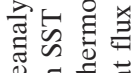

Ð

눈

乙造㐘

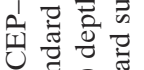

焉记

E

黄焉

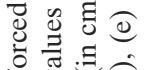

远

물

สี

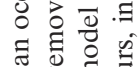

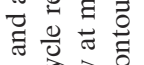

告专

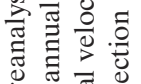

월

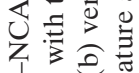
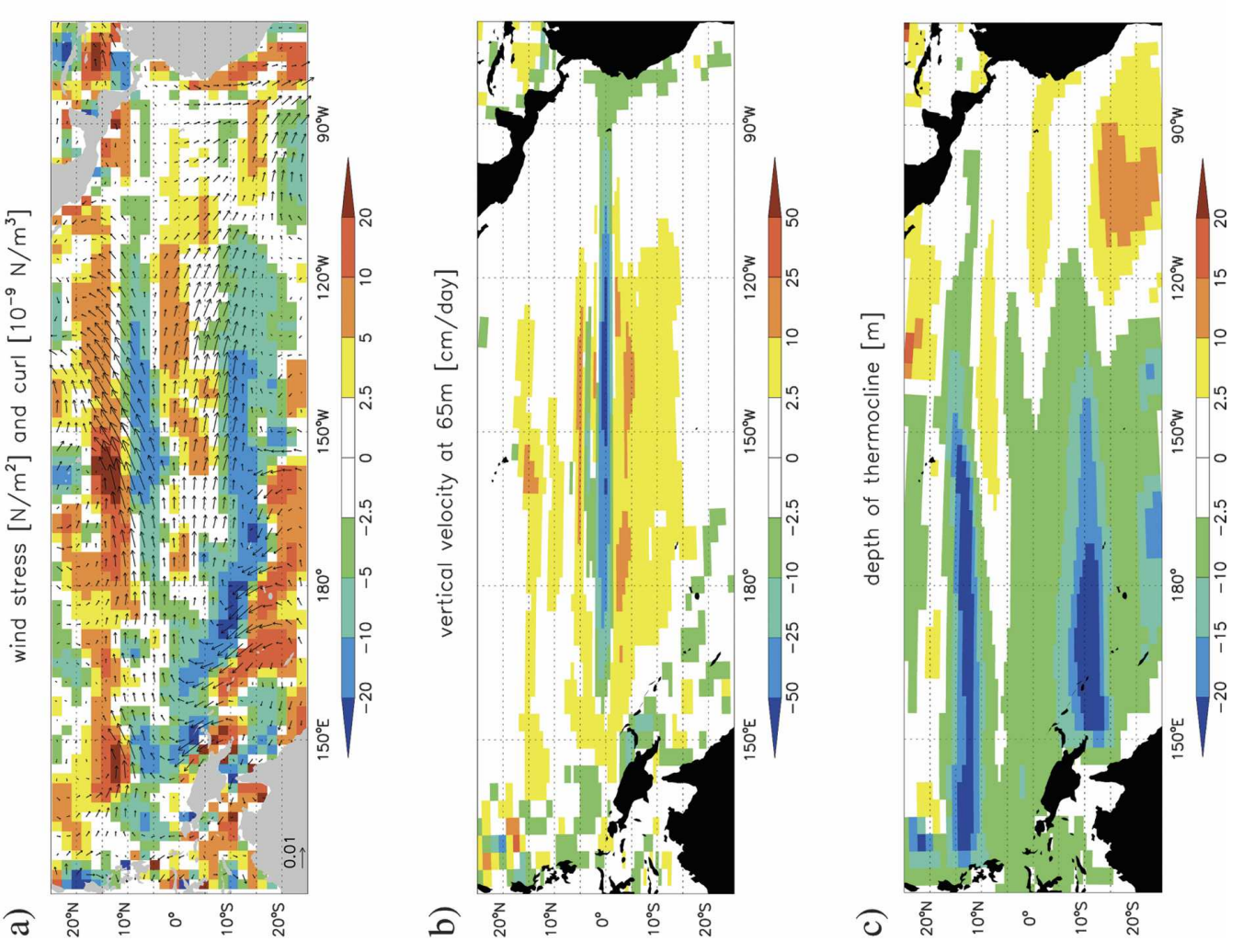

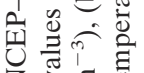

乙

三乙 퐁

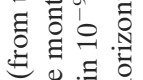

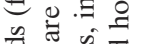

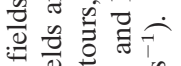

.

过

ชั

政起

号江䓠泀

돔

号吾焉

ส ส

ํํㄹำ

元古至

의 $\cong$ : $\frac{0}{0}$

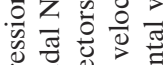

t.

थ प के

교워

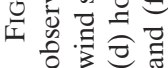


0.01-0.02 $\mathrm{N} \mathrm{m}^{-2}$ per one standard deviation change in the decadal Niño-4 SSTA. In the following, all described changes in the atmospheric and oceanic fields are per standard deviation change of the decadal SSTA index, even if this is not stated explicitly. Furthermore, only the warming case is described.

Weaker trade winds will lead to a reduced Ekman transport divergence in the ocean, which will in turn decrease the equatorial upwelling of colder subsurface water (Fig. 7b). The strongest vertical velocity changes occur in the central Pacific, where the wind stress changes are largest. In the Niño-4 region, a reduction of up to $50 \mathrm{~cm} \mathrm{day}^{-1}$ or about $25 \%$ of the mean upwelling is simulated. This is consistent with the study of McPhaden and Zhang (2002) who describe a strong decrease in the upwelling from the 1970s to the 1990s. The regression pattern for the vertical velocity also shows a weakening of the downwelling at about $5^{\circ}$ latitude reflecting the weakening of the TCs during phases of anomalously warm Niño-4 SST. The effect of the (off) equatorial wind stress onto the variability of the TCs and STCs is discussed below.

A weakening in the trade winds will not only affect the vertical velocity, but will also weaken the winddriven horizontal circulation. Figure 7d (vectors) shows a weakening of the South and North Equatorial Currents (SEC, NEC) of the order of $10 \mathrm{~cm} \mathrm{~s}^{-1}$. Close to the equator, relatively strong meridional velocity anomalies are simulated, which reflect the weaker Ekman divergence during anomalously warm Niño-4 SST. If one considers the mean horizontal temperature gradients in the tropical Pacific, the current anomalies will advect water from the warm pool area zonally toward the east and also meridionally into the equatorial cold tongue. The horizontal temperature advection by the anomalous currents (contours in Fig. 7d) is determined from $-u^{\prime} d \bar{T} / d x-v^{\prime} d \bar{T} / d y$, where the horizontal current anomalies are taken from the corresponding regression pattern (vectors in Fig. 7d), and the mean temperature gradients from the observed SST data. This horizontal advection contribution of the anomalous currents exhibits the strongest warming tendency in the region of the SEC. Splitting the advection of the mean temperature up into the zonal and meridional part (not shown) reveals the same order of magnitude for the two components in the Niño-4 region (up to about $3 \times 10^{-8}$ $\mathrm{K} \mathrm{s}^{-1}$ ). For comparison, we calculate an estimate of the vertical advection by the anomalous vertical velocity according to $-w_{65 \mathrm{~m}}^{\prime}\left(T_{\text {surface }}-T_{90 \mathrm{~m}}\right) / 90 \mathrm{~m}$. At model level $65 \mathrm{~m}$, the upwelling reaches its maximum, but values of about $25 \mathrm{~cm} \mathrm{day}^{-1}$ are simulated down to a depth of $90 \mathrm{~m}$. We estimate from the Levitus data the vertical temperature gradient to be $1-1.5 \mathrm{~K}$ over the upper $90 \mathrm{~m}$ in the warm pool area, which gives (taking $w_{65 \mathrm{~m}}^{\prime}=25 \mathrm{~cm} \mathrm{day}^{-1}$ ) a value of about $4 \times 10^{-8} \mathrm{~K} \mathrm{~s}^{-1}$. This value is quite similar to the estimate of the horizontal advection of the mean temperature by the anomalous horizontal currents in the Niño-4 area.

The subsurface circulation weakens also during periods of anomalously warm Niño-4 SST (Fig. 7f). The Equatorial Undercurrent (EUC) is reduced by the order of $10 \mathrm{~cm} \mathrm{~s}^{-1}$. Shown are the horizontal current anomalies at a depth of $150 \mathrm{~m}$, that is, the core depth of the EUC in the central Pacific. Goes and Wainer (2003) found in an NCEP-NCAR-forced ocean general circulation model similar reductions for the Atlantic Ocean. The EUC and SEC transports decrease (increase) for an anomalously warm (cold) equatorial Atlantic SST. It may be noteworthy that the western boundary currents show, in contrast to the interior pycnocline transport, a strengthening during phases of anomalously warm Niño-4 SST. This is consistent with Lee and Fukumori (2003) who also describe an anticorrelation between the variations of the boundary currents and those of the interior pycnocline transport.

The surface heat flux can change the sea surface temperature in addition to the ocean dynamics. Figure 7e suggests a damping effect of the heat flux upon the SST over most of the equatorial Pacific. In the Northern Hemispheric part of the Niño-4 region, however, the heat flux is contributing to the warming. The wind stress curl anomalies are also shown in Fig. 7a (contours). A wind stress curl anomaly favoring Ekman upwelling $\left(w_{e} \sim \operatorname{curl} \tau / f\right)$ is simulated between about $10^{\circ}$ and $15^{\circ}$ latitude in both hemispheres during phases of anomalously warm Niño-4 SST. In the southwest, the negative anomalies are due to a shift in the South Pacific convergence zone (SPCZ), as is clearly seen in the regression pattern for the precipitation (not shown). The effect of the off-equatorial wind stress curl anomalies is also visible in the vertical velocity (Fig. 7b) and the depth of the thermocline (Fig. 7c). Anomalous upwelling and a shoaling of the thermocline are found at about $10^{\circ}-15^{\circ}$ latitude during anomalously warm Niño-4 SST. Capotondi et al. (2003), using an OGCM forced with fluxes of momentum, heat, and freshwater based on the NCEP-NCAR reanalysis for the period 1958-97, describe strong thermocline variability along $10^{\circ} \mathrm{S}$ and $13^{\circ} \mathrm{N}$ and suggest that it is associated with long first-mode baroclinic Rossby waves. The changes in the depth of the thermocline might contribute to the spindown of the STCs. Merryfield and Boer (2005) suggest a controlling of the pycnocline transport changes due to the wind stress curl. Apart from the weakening of the off-equatorial downwelling, the shoaling of the thermocline in the west will decrease the zonal slope of the 


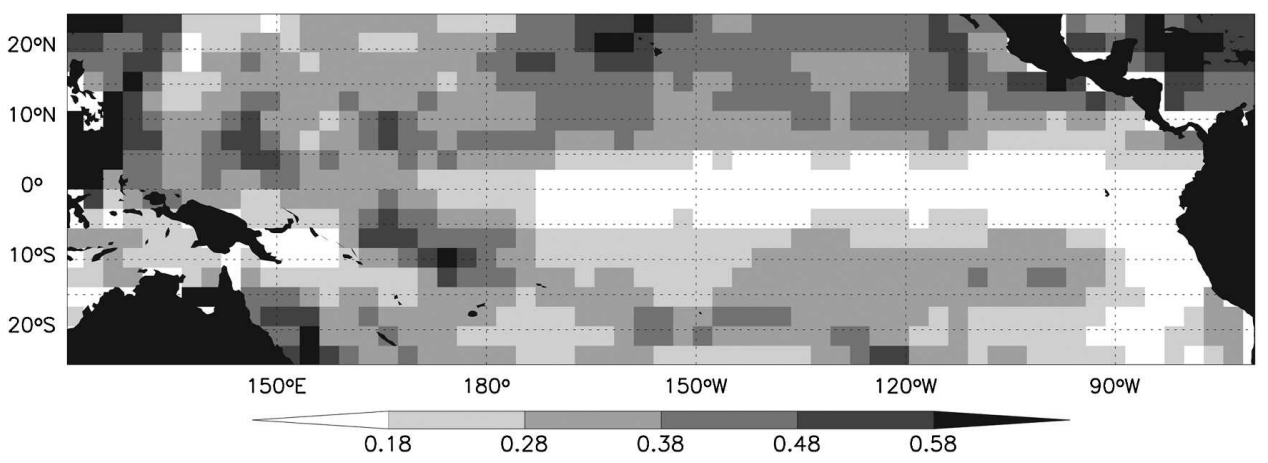

FIG. 8. Potential predictability for decadal observed SST defined by variance of decadal means divided by the total variance. The $95 \%$ significance level according to an $F$ test is 0.38 .

thermocline, which itself might reduce the equatorward flow within the thermocline. Time series of the tilt of the thermocline at about $10^{\circ}$ latitude show a decreasing trend consistent with the decreasing strength of the STCs. Correlation coefficients between the anomalous thermocline depth and the STC strength at $10^{\circ}$ latitude as well as between the anomalous wind stress curl and the STC strength amount to about 0.7 for the Northern and to about 0.6 for the Southern Hemisphere.

To investigate the effects of the equatorial and offequatorial wind stress variability upon the variability of the TCs and STCs, the results from two wind sensitivity experiments with the MPI-OM model forced with the NCEP-NCAR reanalysis have been analyzed. In the two experiments climatological wind stress forcing is prescribed between $5^{\circ} \mathrm{S}$ and $5^{\circ} \mathrm{N}$ or poleward of $5^{\circ}$ latitude, respectively. Indices have been calculated for the decadal strength of the TCs and the STCs in the same way as described for the control run at the beginning of this section. For the TCs, nearly all variability of the cell strength seen in the control run is simulated with wind stress variability restricted only to the equatorial region. The off-equatorial wind stress fluctuations do not significantly affect the TCs. In contrast, the variability of the strength of the STCs is generated mostly by wind stress (curl) fluctuations poleward of $5^{\circ}$ latitude. This indicates that the off-equatorial winds have an influence on the equatorial SST in the western tropical Pacific. It is noteworthy that for the variability of the STCs the effects of the equatorial and off-equatorial wind stresses add up linearly (the sum of the STC indices from the two wind sensitivity experiments resembles the index from the control run).

The relationship between the tropical SST and the strength of the TCs and STCs might give rise to some predictability at decadal time scales. In Fig. 8, the potential predictability (decadal variance/total variance) of the observed SST in the tropical Pacific is shown.
While the potential predictability is close to zero in the typical ENSO region, the eastern and central equatorial Pacific, it is significant in some parts of the western equatorial Pacific and off the equator. These are basically the regions in which the decadal mode explains most of the variance (Fig. 4a). Also these are the regions where long Rossby waves are amplified in baroclinically unstable regions of the subtropical gyre (Galanti and Tziperman 2003). Classical predictability studies with a CGCM, in which our ocean model is used as the ocean component, confirm the results of our potential predictability analysis and show predictive skill in exactly the same regions (Pohlmann et al. 2004).

\section{Simulations with a coupled general circulation model}

We now turn to the decadal variability in the tropical Pacific as simulated by the coupled ocean/atmosphere general circulation model ECHAM4/OPYC in a $300-y r-l o n g$ control integration with constant greenhouse gas concentrations. Figure 9 shows the low-passfiltered (applying a 5-yr running mean) model time series of the Niño-4 SSTA and the maximum strength of the TCs derived from Pacific meridional overturning streamfunction data with a 5-yr running mean applied. The level of the simulated SST variability is of the order of the observed one (Fig. 1). However, no strong trend is found in the control integration with the coupled model. The fluctuations of the TCs and STCs (not shown) are comparable to those from the NCEPNCAR-forced ocean model simulation, in the following denoted as MPI-OM, before and after 1975. However, a change of the cell strength like the one that occurred in the mid-1970s is not found in the coupled model integration. This is in accord with Merryfield and Boer (2005) who also found less pycnocline transport variability in their coupled control run than McPhaden and 

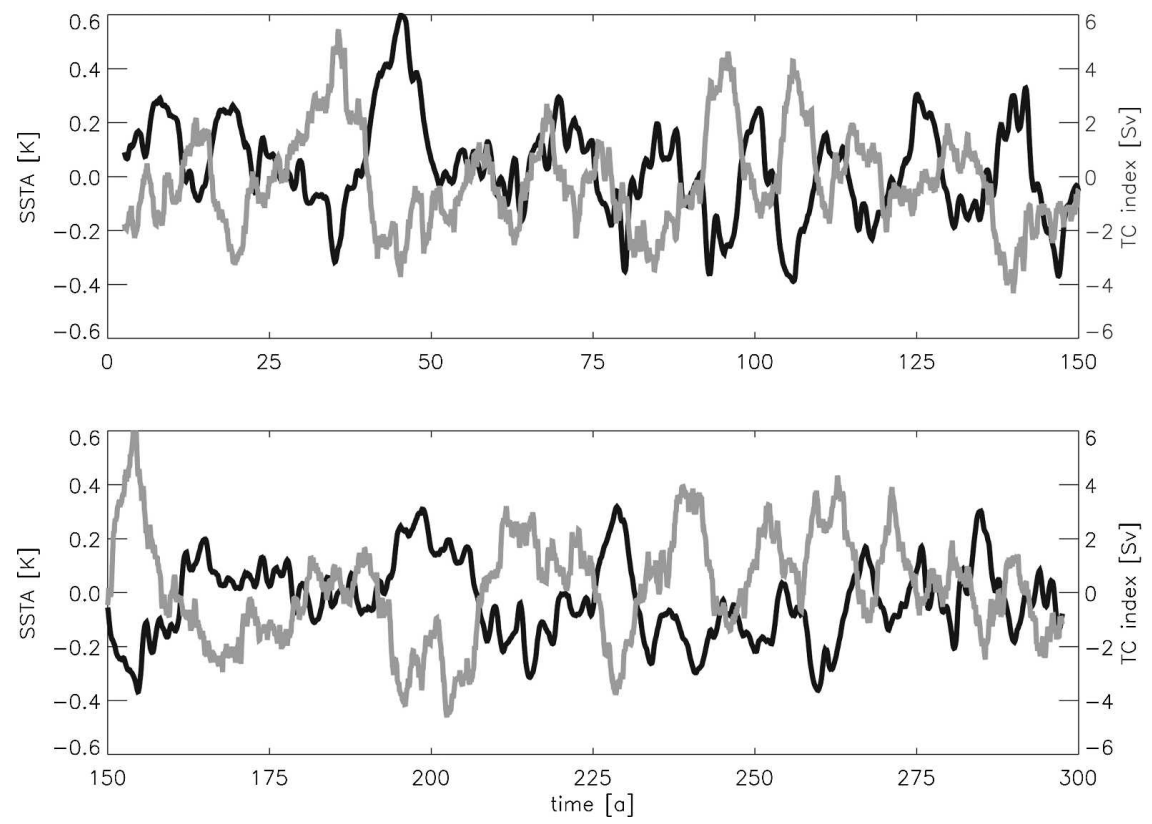

FIG. 9. Time series of the Niño-4 SST anomalies and the anomalous strength of the TCs from the ECHAM4/OPYC model. For definition of the cell strength see text. Shown are only 5-yr running mean values (black for SST, gray for TC).

Zhang (2002) estimated from hydrographic observations. It should be mentioned, however, that the mean strength of the cells is weaker in ECHAM4/OPYC than in MPI-OM (30 Sv compared to $40 \mathrm{~Sv}$ for the southern and $11 \mathrm{~Sv}$ compared to $25 \mathrm{~Sv}$ for the northern TC).

Also for the coupled integration, the low-passfiltered Niño-4 SST and time series of the strength of the TCs and STCs (not shown) are anticorrelated. For the TCs, the maximum correlation coefficient amounts to -0.7 . The same correlation is found for the decadal observed Niño-4 SSTAs and STC strength anomalies from MPI-OM. However, in ECHAM4/OPYC the maximum correlation is found at lag zero. This lag is influenced by both hemispheric cells. While the northern TC is leading the SST by about 6 month, no such lag is found for the southern TC. The reason for this is not yet clear. Considering the decadal strength of the STCs, the strongest (anti) correlation amounts to about -0.45 (Fig. 10), which is weaker than for MPI-OM, but still statistically significant at the $95 \%$ level (threshold value -0.21 according to a $t$ test). The fact that the cells are weaker compared to MPI-OM might contribute to the lower correlation, although the correlation is similar if the TCs are considered. The regression pattern of the Pacific meridional overturning streamfunction upon the low-pass-filtered Niño-4 SSTA (not shown) also suggests a weaker influence from off-equatorial regions than in MPI-OM. As in MPI-OM, the strongest (anti) correlation is found if the strength of the STCs is lead- ing the Niño-4 SSTAs by about $1 \mathrm{yr}$. Thus, the CGCM integration supports our notion that the low-frequency variability in the STCs is important in driving western equatorial and off-equatorial SST anomalies. For the STCs, the lag is similar for both hemispheres. A secondary extreme is found in the cross-correlation function, when the Niño-4 SSTAs are leading the strength of the STCs. This suggests that changes in the SST might contribute (via changes in the trade winds) to

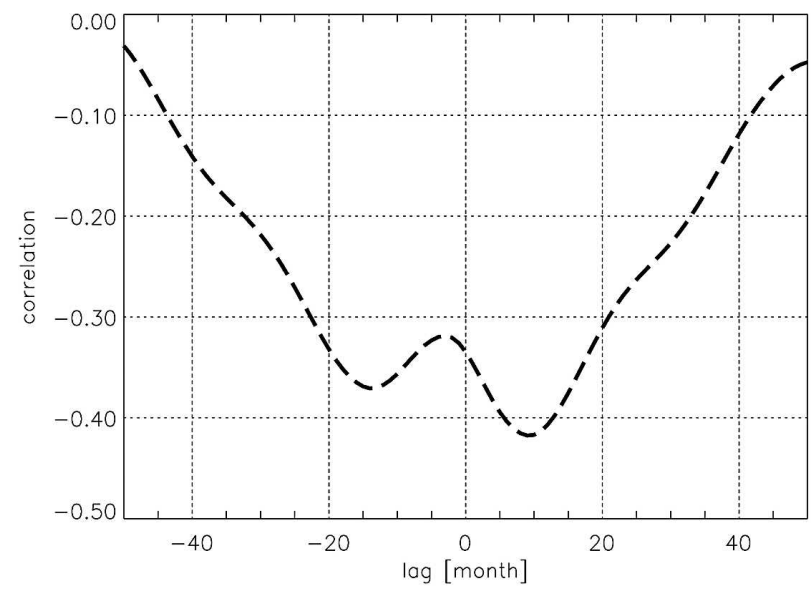

FIG. 10. Cross-correlation function between the decadal Niño-4 SST (Fig. 9) and the strength of the STCs from the ECHAM4/ OPYC model. For definition of the cell strength see text. The $95 \%$ significance level according to a $t$ test is -0.21 . A positive (negative) lag indicates that the Niño-4 SST is lagging (leading). 
changes in the cell strength. Such a feedback is not seen in the uncoupled OGCM run (long-dashed line in Fig. 5). It is found, however, if the MPI-OM model is coupled to the atmosphere model ECHAM5 (not shown). The correlation pattern (not shown) between the TC as well as the STC strength index and the SST in the tropical Pacific shows a horseshoe-like structure with maximum correlation in the western equatorial Pacific and off the equator also for the coupled model, resembling that shown in Fig. 4a.

We performed again an SSA of the monthly Niño-4 SSTA and reconsidered the two leading modes. In contrast to the observed SST, the leading SSA mode of the coupled model has an interannual time scale representing the ENSO mode, while the second-most energetic mode is the decadal mode. This seems to be due to the fact that the coupled model simulates an El Niño period of only $2 \mathrm{yr}$ and slightly too strong ENSO variability. If the SSA is calculated from annual values rather than from monthly values so that the ENSO frequency is not fully resolved, the decadal mode turns out to be the leading one. We regress various atmospheric and oceanic fields onto the decadal Niño-4 SSTA mode. The regression patterns derived from the CGCM (Fig. 11) are similar to the ones derived from MPI-OM (Fig. 7) in many aspects. There are, however, significant differences, which will be discussed below. If one takes into account the different standard deviations of the decadal Niño-4 SSTA modes $\left(0.13^{\circ} \mathrm{C}\right.$ for the CGCM compared to $0.21^{\circ} \mathrm{C}$ for the observed one), the values have the same order of magnitude. We note that the scale in Fig. 11 is different than that in Fig. 7 and that in both cases the regression coefficients are expressed per standard deviation in the SSTA. Again, only the case of anomalously warm Niño-4 SST is described.

In ECHAM4/OPYC, the weakening of the surface wind stress (vectors in Fig. 11a), as well as the upwelling favorable curl at about $10^{\circ}$ latitude (contours in Fig. 11a) during an increase in the Niño-4 SST, are confined to the western part of the basin. This is also the case if the SST index is averaged over the entire width of the Pacific. In MPI-OM, the dominant change is the relatively strong trend in the mid-1970s (e.g., Fig. 1). If the observed Niño-4 SST index as well as the wind stress (curl) from the NCEP-NCAR reanalysis are detrended prior to the calculation of the regression coefficients, the regression pattern for MPI-OM also shows a weakening of the trades between about $15^{\circ} \mathrm{S}$ and $15^{\circ} \mathrm{N}$ as well as an upwelling-favorable curl at about $10^{\circ}$ latitude only in the western part of the Pacific. According to the wind stress pattern in ECHAM4/OPYC (vectors in Fig. 11a), the maximum equatorial upwelling anomalies are simulated in the west (Fig. 11b) where the mean vertical velocity is relatively small.

Considering the horizontal surface circulation during phases of anomalously warm Niño-4 SST (Fig. 11d), the weakening of the South Equatorial Current (SEC) is quite strong in the east. This is at least partly due to the fact that the mean SEC is relatively strong in the east in the ECHAM4/OPYC model $\left(70 \mathrm{~cm} \mathrm{~s}^{-1}\right.$ compared to 50 $\mathrm{cm} \mathrm{s}^{-1}$ in MPI-OM). In the west, a wind-driven equatorial jet is simulated by the CGCM, flowing eastward during anomalously warm Niño-4 SST. Due to this jet and the strengthening of the North Equatorial Countercurrent (NECC), the horizontal temperature advection (contours in Fig. 11d) contributes, in contrast to MPI-OM, to an increase of the Niño-4 SST north of the equator. As for the wind stress pattern, the difference between the two simulations seems to be due to the relatively strong trend found in the MPI-OM simulation. If the observed Niño-4 SST index as well as the simulated horizontal velocities are detrended prior to the regression analysis, the regression pattern for MPIOM shows an equatorial jet in the west too.

For the subsurface circulation (Fig. 11f) it should be mentioned that the Equatorial Undercurrent (EUC) is reduced over the whole width of the basin. Since the EUC core rises toward the east, the changes in the east are visible in the regression patterns for model levels 50 and $100 \mathrm{~m}$ (not shown). The net surface heat flux (Fig. 11e) in ECHAM4/OPYC also contributes to the warming in the northwestern equatorial Pacific, although this contribution is confined to the region west of the date line. Considering the changes in the depth of the thermocline during anomalously warm Niño-4 SST (Fig. 11c), the shoaling of the thermocline in the western and central parts is much weaker in ECHAM4/OPYC than in MPI-OM. In contrast, the deepening of the thermocline in the east is more pronounced in the CGCM simulation. As discussed before, the main reason for the difference between the two simulations is the relatively strong trend found in MPI-OM. Time series of the depth of the thermocline at about $10^{\circ}$ latitude in the western and central tropical Pacific in MPI-OM show a decreasing trend of up to $85 \mathrm{~m}$. Such a signal is not found in the ECHAM4/OPYC control simulation. Compared to observations, however, the trend in the depth of the thermocline is overestimated in MPI-OM. We derived observed time series of the depth of the thermocline for the period 1955-2003 using temperature data from the Joint Environmental Data Analysis Center (JEDAC; Tourre and White 1995). The observed changes in the depth of the thermocline are only about half of those simulated by MPI-OM. Again, if the observed Niño-4 SST index and the simulated ther- 

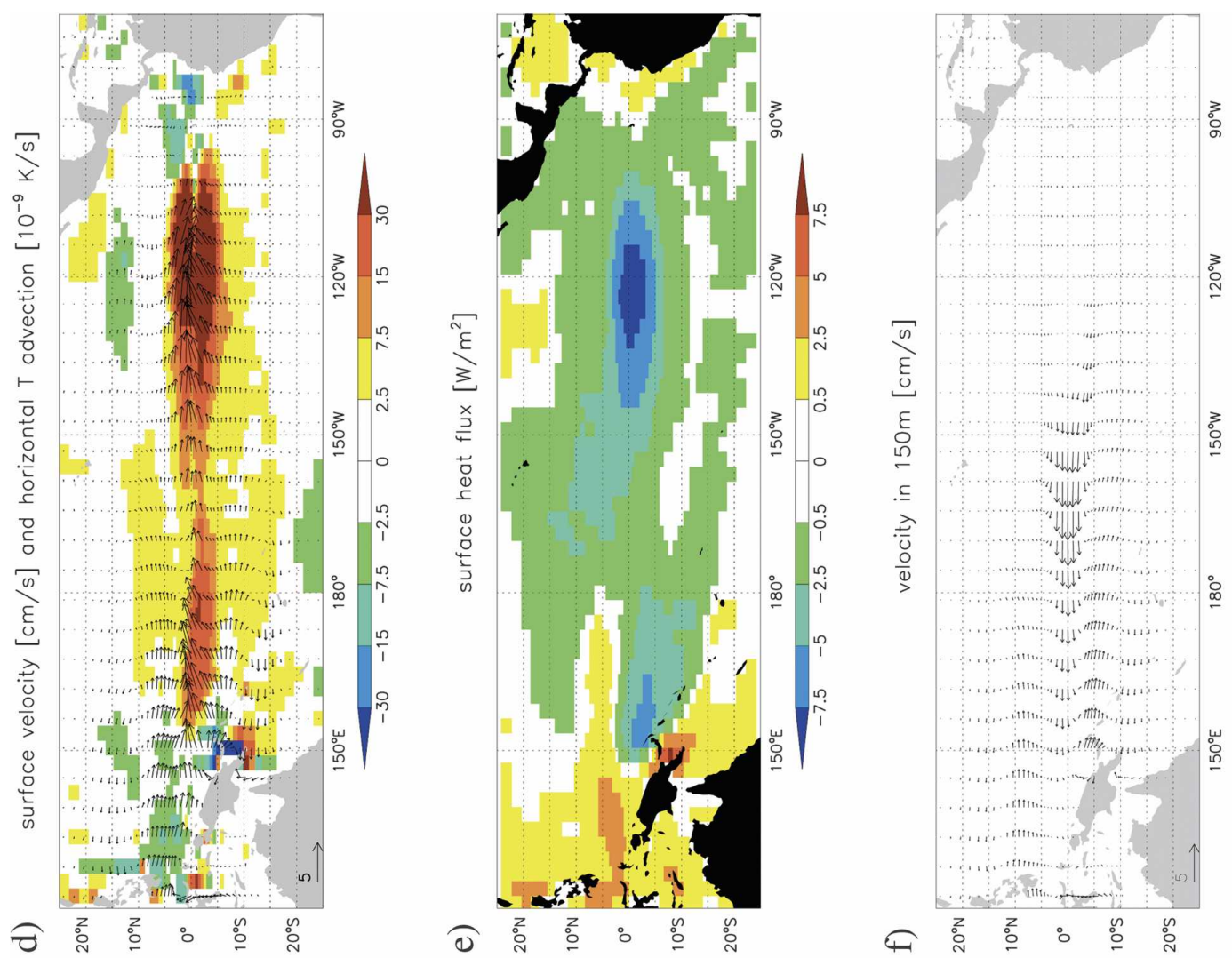

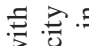

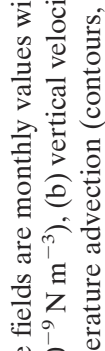

롵을 훙

可

응

○ิ ज :

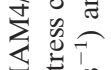

焉焉的

피 局领

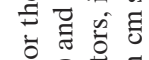

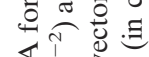

羟过

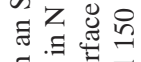

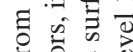

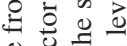

류

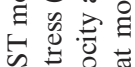
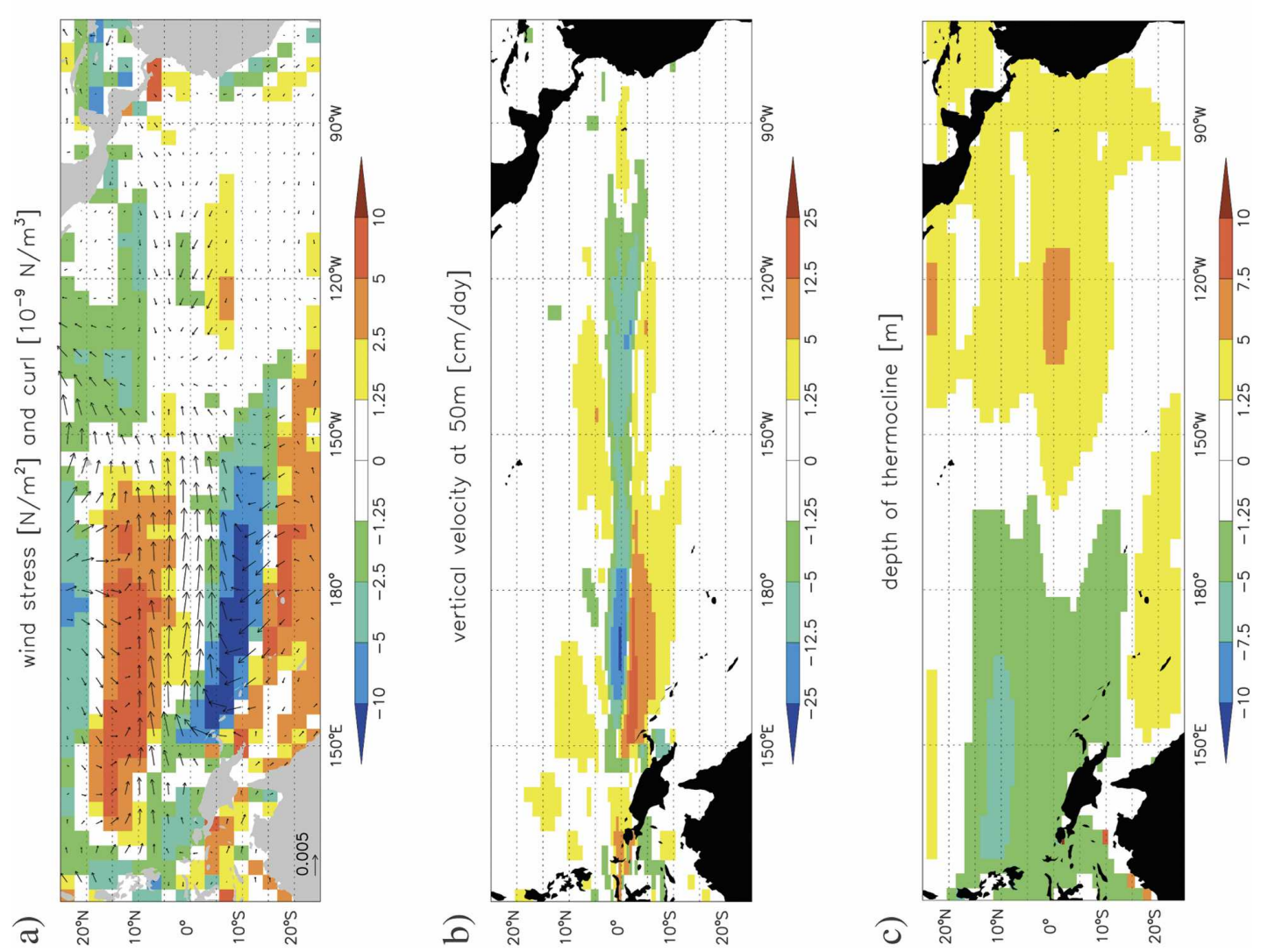

की क⿱ के

约 픈

需谷需



ङ월

氞宝 豞可

ํ.

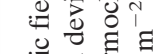

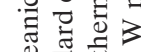

过需

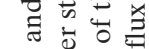

.

क्षे एँ

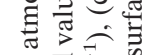

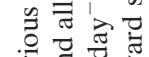

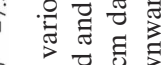

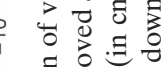

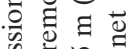

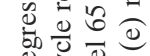

$\therefore$ 过:

$\exists$ 플

응

它焉 

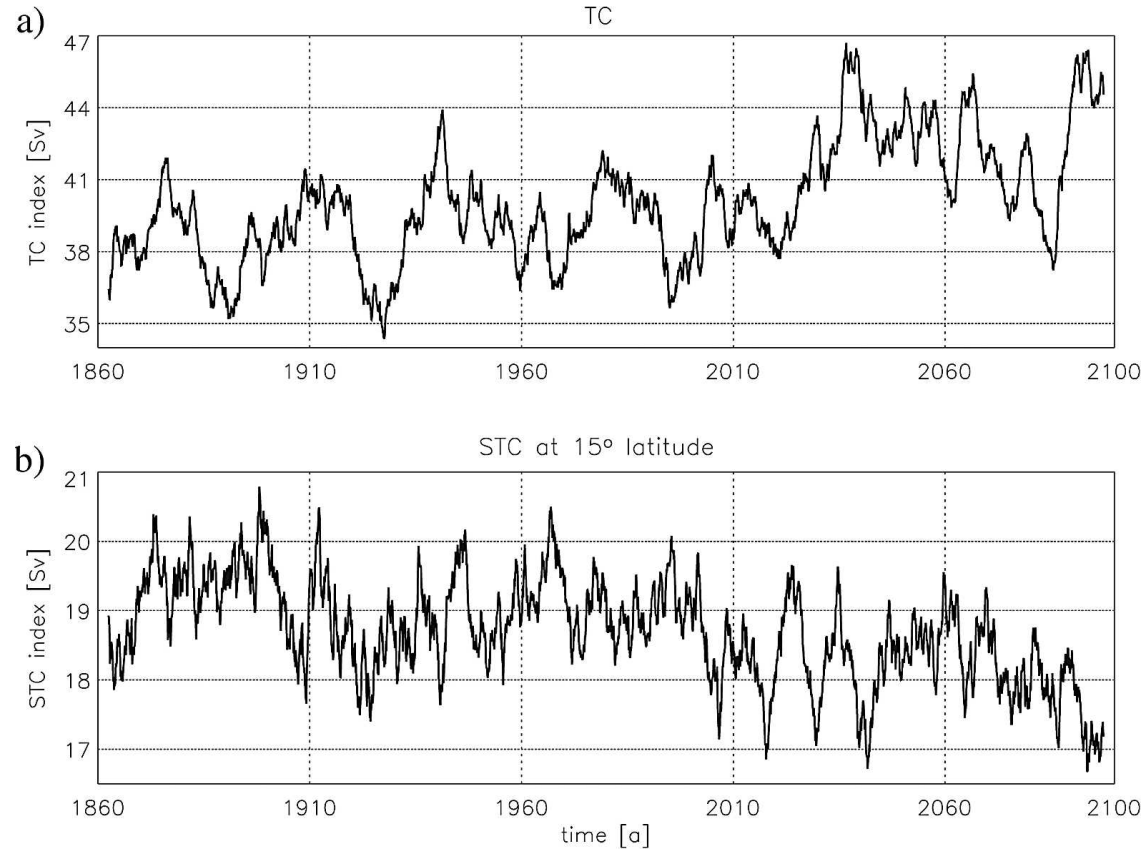

FIG. 12. Time series of the anomalous strength of the (a) TCs and (b) STCs at $15^{\circ}$ latitude from a scenario run of the ECHAM4/OPYC model. For definition of the cell strength see text. Shown are only 5 -yr running mean values.

mocline depth are detrended prior to the calculation of the regression coefficients, the regression pattern for MPI-OM also shows much weaker shoaling of the thermocline in the western and central parts and stronger deepening of the thermocline in the area of the cold tongue.

Apart from the control integration, a 240-yr-long scenario integration is available from the ECHAM4/ OPYC model to study the sensitivity of the TCs and STCs to greenhouse warming. This integration was analyzed, for instance, by Timmermann et al. (1999) who investigated the ENSO response to greenhouse warming. The integration is forced by observed greenhouse concentrations from 1860 to the present, and the concentrations follow the IPCC 1992a scenario until 2100. As for the control integration, we compute indices for the strength of the TCs and STCs as described at the beginning of section 4. Additionally, we compute an STC index at $15^{\circ}$ latitude. Figure 12a shows the time series of the strength of the TCs in the scenario integration. The strength is obviously increasing under greenhouse conditions. Such a trend is not seen in the control integration (Fig. 9). Considering the strength of the STCs, the model simulates a decreasing trend poleward of $10^{\circ}$ latitude. This is seen clearly at $15^{\circ}$ latitude (Fig. 12b), where the transport weakens considerably during the twenty-first century. Thus, the CGCM simulates a quite complex global warming response of the tropical circulation. While the tropical cells intensify, the off-equatorial and deeper overturning spins down (Fig. 13). The latter is consistent with Merryfield and Boer (2005) who found a decrease of the pycnocline transport at $10^{\circ}$ latitude under global warming condi-

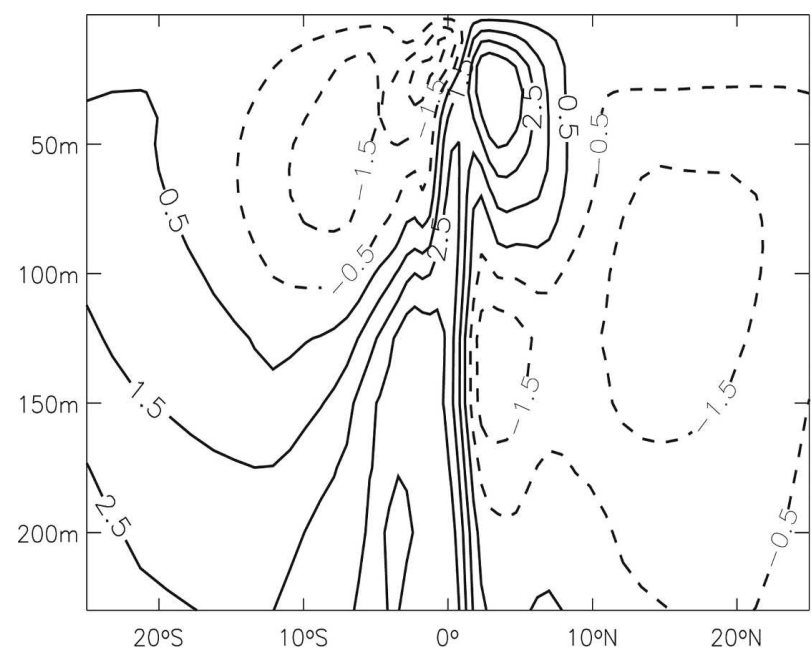

FIG. 13. Trend in the Pacific meridional overturning streamfunction from a scenario integration of the ECHAM4/OPYC model. Units are Sv over the last $110 \mathrm{yr}$ of the integration (1990$2100)$. Contour levels are $\pm 0.5,1.5,2.5$, and $3.5 \mathrm{~Sv}$. Note that for the Southern Hemisphere the mean overturning is negative; i.e., negative (positive) values correspond to a strengthening (weakening). 
tions. A more detailed discussion of the results of the scenario integration is beyond the scope of this paper.

\section{Conclusions}

In this paper we have investigated the origin of the decadal SST variability in the tropical Pacific. The leading mode in the western equatorial Pacific is a decadal mode. Its spatial structure is El Niño like, but it explains most variance in the western equatorial Pacific and off the equator. The warming trend observed during the most recent decades projects onto the decadal mode. Our analysis suggests that the decadal variability (including the trend) is closely connected to the variability of the wind-driven tropical and subtropical cells (TCs, STCs). Changes in the strength of the cells lead the changes in SST. The lag becomes larger with increasing latitude, which indicates that the STCs adjust slower than the TCs. Different processes play important roles in the connection between the cells and the SST, including vertical and horizontal advection of the mean temperature by anomalous currents. The surface heat flux acts in most regions as a damping. Thus, it is the ocean dynamics that drive the decadal SST variability in large regions of the tropical Pacific. In the eastern equatorial Pacific, the variability of the TCs and STCs does not explain much of the SST variability. The SST in this region is mainly determined by the depth of the thermocline. In the NCEP-NCAR-forced ocean model simulation as well as in the coupled model simulation, correlation coefficients between the SST anomalies and anomalies of the depth of the thermocline are of the order of $0.8-0.9$ for interannual as well as decadal time scales.

The results of the coupled control integration suggest the existence of a coupled feedback loop between the SST and the STCs. One possible feedback hypothesis is described in the following. We start the loop with anomalously strong (weak) STCs. These in turn will drive colder (warmer) SSTs in the equatorial Pacific that are La Niña (El Niño) like. The SST anomalies will force characteristic off-equatorial wind stress curl anomalies, eventually weakening (strengthening) the STCs, which completes the phase reversal. Further work is needed, however, to prove this hypothesis. The results of a greenhouse warming integration with the same coupled model reveal a strengthening of the TCs, but a weakening of the off-equatorial and deeper overturning.

Acknowledgments. We thank Dr. Noel Keenlyside for helpful discussion during all stages of the work and Monika Esch for helping with the OPYC data. Two anonymous reviewers are thanked for their helpful comments on an earlier version of the manuscript. This work was supported by the Ocean-CLIVAR program of the BMBF and the DYNAMITE project of the European Union. The numerical model integrations were performed at the Deutsches Klimarechenzentrum.

\section{REFERENCES}

Barnett, T., D. Pierce, M. Latif, D. Dommenget, and R. Saravanan, 1999: Interdecadal interactions between the tropics and midlatitudes in the Pacific basin. Geophys. Res. Lett., 26, 615-618.

Capotondi, A., M. Alexander, and C. Deser, 2003: Why are there Rossby wave maxima in the Pacific at $10^{\circ} \mathrm{S}$ and $13^{\circ} \mathrm{N}$ ? J. Phys. Oceanogr., 33, 1549-1563.

Galanti, E., and E. Tziperman, 2003: A midlatitude-ENSO teleconnection mechanism via baroclinically unstable long Rossby waves. J. Phys. Oceanogr., 33, 1877-1888.

Giese, B., S. Urizar, and N. Fuckar, 2002: Southern Hemisphere origins of the 1976 climate shift. Geophys. Res. Lett., 29, 1014, doi:10.1029/2001GL013268.

Goes, M., and I. Wainer, 2003: Equatorial currents transport changes for extreme warm and cold events in the Atlantic Ocean. Geophys. Res. Lett., 30, 8006, doi:10.1029/ 2002 GL015707.

Graham, N., 1994: Decadal-scale climate variability in the tropical and North Pacific during the 1970s and 1980s: Observations and model results. Climate Dyn., 10, 135-162.

Gu, D., and S. Philander, 1997: Interdecadal climate fluctuations that depend on exchanges between the tropics and extratropics. Science, 275, 805-807.

Hazeleger, W., M. Visbeck, M. Cane, A. Karspeck, and N. Naik, 2001: Decadal upper ocean temperature variability in the tropical Pacific. J. Geophys. Res., 106, 8971-8988.

_ P. DeVries, and Y. Friocourt, 2003: Sources of the Equatorial Undercurrent in the Atlantic in a high-resolution ocean model. J. Phys. Oceanogr., 33, 677-693.

Houghton, J., L. Meira Filho, B. Callendar, N. Harris, A. Kattenberg, and K. Maskell, Eds., 1995: Climate Change 1995: The Science of Climate Change. Cambridge University Press, 572 pp.

Johnson, G., 2001: The Pacific Ocean subtropical cell surface limb. Geophys. Res. Lett., 28, 1771-1774.

Kalnay, E., and Coauthors, 1996: The NCEP/NCAR 40-Year Reanalysis Project. Bull. Amer. Meteor. Soc., 77, 437-471.

Kleeman, R., J. McCreary, and B. Klinger, 1999: A mechanism for generating ENSO decadal variability. Geophys. Res. Lett., 26, 1743-1746.

Klinger, B., J. McCreary, and R. Kleeman, 2002: The relationship between oscillating subtropical wind stress and equatorial temperature. J. Phys. Oceanogr., 32, 1507-1521.

Latif, M., R. Kleeman, and C. Eckert, 1997: Greenhouse warming, decadal variability, or El Niño: An attempt to understand the anomalous 1990s. J. Climate, 10, 2221-2239.

—- and Coauthors, 2004: Reconstructing, monitoring, and predicting decadal-scale changes in the North Atlantic thermohaline circulation with sea surface temperature. J. Climate, 17, 1605-1614.

Lee, T., and I. Fukumori, 2003: Interannual-to-decadal variations of tropical-subtropical exchange in the Pacific Ocean: 
Boundary versus interior pycnocline transports. J. Climate, 16, 4022-4042.

Liu, Z., 1994: A simple model of the mass exchange between the subtropical and tropical ocean. J. Phys. Oceanogr., 24, 11531165.

- 1998: The role of ocean in the response of tropical climatology to global warming: The west-east SST contrast. J. Climate, 11, 864-875.

Lu, P., J. McCreary, and B. Klinger, 1998: Meridional circulation cells and the source waters of the Pacific Equatorial Undercurrent. J. Phys. Oceanogr., 28, 62-84.

Marsland, S., H. Haak, J. Jungclaus, M. Latif, and F. Roeske, 2003: The Max-Planck-Institute global ocean/sea ice model with orthogonal curvilinear coordinates. Ocean Modell., 5, 91-127.

McCreary, J., and P. Lu, 1994: Interaction between the subtropical and equatorial ocean circulations: The subtropical cell. $J$. Phys. Oceanogr., 24, 466-497.

McPhaden, M., and D. Zhang, 2002: Slowdown of the meridional overturning circulation in the upper Pacific Ocean. Nature, 415, 603-608.

Merryfield, W., and G. Boer, 2005: Variability of upper Pacific Ocean overturning in a coupled climate model. J. Climate, 18, 666-683.

Nonaka, M., S.-P. Xie, and J. McCreary, 2002: Decadal variations in the subtropical cells and equatorial Pacific SST. Geophys. Res. Lett., 29, 1116, doi:10.1029/2001GL013717.

Oberhuber, J., 1993: Simulation of the Atlantic circulation with a coupled sea ice-mixed layer-isopycnal general circulation model. Part I: Model description. J. Phys. Oceanogr., 23, 808829.

Pohlmann, H., M. Botzet, M. Latif, A. Roesch, M. Wild, and P. Tschuck, 2004: Estimating the decadal predictability of a coupled AOGCM. J. Climate, 17, 4463-4472.

Rayner, N., D. Parker, E. Horton, C. Folland, L. Alexander, D.
Rowell, E. Kent, and A. Kaplan, 2003: Global analyses of SST, sea ice, and night marine air temperature since the late nineteenth century. J. Geophys. Res., 108, 4407, doi:10.1029/ 2002JD002670.

Roeckner, E., and Coauthors, 1996: The atmospheric general circulation model ECHAM-4: Model description and simulation of present-day climate. Max-Planck-Institut für Meteorologie Rep. 218, Hamburg, Germany, 90 pp.

- L. Bengtsson, J. Feichter, J. Lelieveld, and H. Rohde, 1999: Transient climate change simulations with a coupled atmosphere-ocean GCM including the tropospheric sulfur cycle. $J$. Climate, 12, 3004-3032.

Schneider, N., S. Venzke, A. Miller, D. Pierce, T. Barnett, C. Deser, and M. Latif, 1999: Pacific thermocline bridge revisited. Geophys. Res. Lett., 26, 1329-1332.

Solomon, A., J. McCreary, R. Kleeman, and B. Klinger, 2003: Interannual and decadal variability in an intermediate coupled model of the Pacific region. J. Climate, 16, 383-405.

Timmermann, A., M. Latif, A. Bacher, J. Oberhuber, and E. Roeckner, 1999: Increased El Niño frequency in a climate model forced by future greenhouse warming. Nature, 398, 694-696.

Tourre, Y., and W. White, 1995: ENSO signals in global upperocean temperature. J. Phys. Oceanogr., 25, 1317-1332.

Trenberth, K., and J. Hurrell, 1994: Decadal atmosphere-ocean variations in the Pacific. Climate Dyn., 9, 303-319.

Wu, R., and S.-P. Xie, 2003: On equatorial Pacific wind changes around 1977: NCEP-NCAR reanalysis versus COADS observations. J. Climate, 16, 167-173.

Zhang, R.-H., L. Rothstein, and A. Busalacchi, 1998: Origin of upper-ocean warming and El Nino change on decadal scales in the tropical Pacific Ocean. Nature, 391, 879-883.

Zhang, Y., J. Wallace, and D. Battisti, 1997: ENSO-like interdecadal variability: 1900-93. J. Climate, 10, 1004-1020. 